\title{
The Social and Eocnomic Impacts of the Global Financial and Economic Crisis
}

\author{
Dr. A. Sundaram, \\ Dept. of Economics, Govt Saiha College, Mizoram Central University, Saiha, Mizoram,North East India.
}

\begin{abstract}
This paper examines the social and economic impacts of the global financial and economic crisis and highlights a global jobs crisis involving widespread job losses, increased unemployment and wage repression in developed countries, and characterized by a growing informal economy, increased vulnerable employment and working poverty in developing countries. It briefly reviews the reach of the crisis across demographic and social groups, showing its varied effects on the employment and income of women and men, its disproportionate effect on youth and the strain it imposed on various vulnerable groups in terms of reduced income. In so doing, this paper highlights the dire consequences that individuals and their families face in both developed and developing economies. It concludes by highlighting some of the major challenges faced in addressing the jobs crisis, and suggests that, besides employment generation and income support, other forms of social protection will be of utmost importance in overcoming the effects of the crisis.

The global financial and economic crisis triggered sharp output contractions in almost all industrialized economies in 2009 for the first time in the post-Second World War era. Besides the direct impacts of this contraction in developed economies, subsequent declines in cross-border trade and the rising cost of finance had serious negative effects on emerging and developing economies. In particular, as businesses cut production in response to lower aggregate demand, workers were shed in large numbers, sharply increasing unemployment worldwide.
\end{abstract}

Between 2007 and the end of 2009 there was an unprecedented increase in the numbers unemployed (International Monetary Fund and International Labour Organization, 2010). This reported increase in unemployment most likely underestimates the true depth of the problem, since job loss figures are based on official labour statistics, which in many developing countries only covers employment in the formal economy, mainly in urban areas. Beyond job losses, the quality of employment also deteriorated in both developed and developing countries. Across the globe, many workers who did not lose their jobs were forced to accept reduced working hours as well as lower wages and benefits. In developing countries, a large number of workers lost their jobs in export sectors and were forced into informal and vulnerable employment elsewhere. Although the global economy recovered more quickly than expected largely due to coordinated stimulus packages, unemployment is still high. The situation is being further aggravated by austerity measures in most developed economies. The Great Recession has thus created a jobs crisis.

The increased job insecurity due to the recession has resulted in sustained and devastating impacts on individuals, families, households and their communities. Communities are affected when manufacturing jobs disappear as a result of plant closures or workforce downsizings, or when young people relocate to other cities and towns in search of better job opportunities. Such job losses since 2008 have pushed countless families into financial and economic hardship, resulting in the loss of homes to foreclosure and increases in poverty, debt and bankruptcy, especially in the United States and other advanced economies. Because work is intimately related to several dimensions of individual well-being, job losses and worsening job and economic insecurity have also been associated with increased poor health, psychological hardship and family dissolution (Stucklerand others, 2009b).

The recession has also affected various social and economic groups in very different ways. In general, women have been disproportionately adversely affected, but in some economies, the adverse impacts on men have been more severe than on women. In other economies, less skilled workers, youth, older persons and migrant workers have suffered in terms of lost jobs, benefits and earnings. These effects have also varied across and within regions and countries.

The global economic downturn has had wide-ranging negative social outcomes for individuals, families, communities and societies, and its impact on social progress in areas such as education and health will only become fully evident over time. During times of financial and economic crisis, households often adopt coping strategies, such as making changes in household expenditure patterns; however, these can negatively influence education, health and nutrition outcomes, which may lead to lifelong deficits for the children affected and thus perpetuate the intergenerational transmission of poverty. Given the fragility of the economic recovery and the uneven progress in major economies, social conditions are expected to recover only slowly. The 
increased levels of poverty, hunger and unemployment will continue to affect billions of people for years to come.

\section{Introduction}

Recent globalization has been characterized by widespread trade and capital account liberalization, either voluntarily or as a condition for receiving loans or aid. The dominant view, at least prior to the current crisis, had been that freer markets would enhance economic efficiency. That view held that trade liberalization and economic openness should enable countries to maximize resource use and comparative advantage, attract FDI and increase capital formation. The benefits of the ensuing growth would then trickle down to the majority of the population.

This approach, however, did not achieve the promised results in many countries, and in fact worsened the effects of the crisis (van der Hoeven, 2010). The global crisis was, in part, precipitated by the lack of international regulatory coordination. Globalization of financial markets has meant that much credit and capital are no longer under the jurisdiction of national regulatory bodies. Existing national regulation also proved insufficient to protect investors from excessive risk. Governments' failure to more effectively regulate banks and other financial institutions allowed those institutions to take advantage of loopholes in their search for greater profits, ultimately causing them to become overleveraged (United Nations, 2010b)

Globalization in the years prior to the crisis accelerated the broad economic integration that facilitated the spread throughout the world of the repercussions of unsustainable overleveraging in the United States. The crisis spread through financial market interlinkages across Europe and quickly extended to the real economy as needed loans and investment finance became increasingly unavailable. While the impact of the crisis on economic growth and employment has been most severe in some high-income countries, there have also been negative impacts on developing countries. Declining global trade and commodity prices hurt export sectors, as the credit squeeze spread to developing countries and transition economies.

Global unemployment rose sharply from 178 million persons in 2007 to 205 million in 2009. The rapid rise in unemployment has triggered an increase in vulnerability, especially in developing countries without comprehensive social protection. Estimates suggest that between 47 million and 84 million more people fell into, or remained trapped in, extreme poverty because of the global crisis.

The economic crisis was preceded by the food and fuel price hikes in 2007 and 2008. According to the FAO, the number of people living in hunger in the world rose to over a billion in 2009, the highest on record. These multiple crises have set back the progress many countries have made towards achieving the internationally agreed development goals, including the Millennium Development Goals.

The main aim of this paper is to examine the Social and Eocnomic Impacts of the Global Financial and Economic Crisis. It analyses the Employment Impact, Impact on Informal and Vulnerable Employment, Impact on Working Poor, Impact of the crisis on Wages and Salaries, Adverse impact on Demographic and Social Group, the Impact on Household dynamics and Human development and conclusion.

\section{Employment impacts}

Prior to the crisis, many countries, including high-growth countries, had large numbers of unemployed and working poor, against a declining trend in the employment content of economic growth. The resulting global impact of the crisis on employment has been devastating. Private companies and public institutions shed millions of jobs and froze new hiring as they sought to reduce labour costs to adjust to shrinking demand for their products and services. This action triggered an unprecedented global increase in the number of jobless persons to 205 million by the end of 2009, 27 million more than in 2007 (International Labour Organization, 2011). According to the latest estimates by the International Labour Organization global unemployment remained unchanged in 2010 compared to 2009 - the global unemployment rate stood at 6.2 per cent in 2010.

(International Labour Organization, 2011). Although the number of unemployed in 2010 had shown little change from 2009, global job insecurity rose perceptibly. While preliminary estimates suggested that the number of unemployed in 2010 had shown little change from 2009, global job insecurity rose perceptibly. The extent to which this affected different regions and countries varied significantly with the different impacts of the crisis around the globe. High-income countries have generally experienced greater increases in unemployment than upper-middle-income and lower-middle-income countries.

From 2008 through the first quarter of 2010, high-income countries endured seven consecutive quarters of employment loss, which amounted to over 14 million jobs, with 7 million jobs lost in the first half of 2009 alone. Of the 60 countries with available data at the beginning of 2010, 97 per cent of high-income countries had higher unemployment rates, compared to 78 per cent of upper middle-income countries and 50 per cent of lower-middle-income countries. By the first quarter of 2010, high-income countries had an unemployment rate of about 9 per cent, an increase of more than 3 percentage points over the level of the previous two years. For 
upper-middle income countries, although the unemployment rate was even higher, at more than 10 per cent at the beginning of 2010, the relative increase was not as dramatic.

On the other hand, lower-middle-income countries recorded only marginal increases in the rate of unemployment during the period, with an average just over 6 per cent at the beginning of 2010 (International Labour Organization, International Institute for Labour Studies, 2010).

Of the total increase in global unemployment between 2007 and 2010, 55 per cent occurred in the developed economies and in the European Union group of countries, which account for only 15 per cent of the world's labour force. By the end of 2009, the number of unemployed in this group of countries had risen by nearly 14 million over pre-crisis numbers, an increase of nearly 50 per cent. This increase in the numbers unemployed was far greater than in any other group of countries, more than double the increase of 6 million recorded in East Asia. The unemployment rate also rose most steeply in the developed economies and the European Union group of countries, increasing from 5.8 to 8.4 per cent between 2007 and 2009 (International Labour Organization, 2011).

While economic growth in developed economies and European Union countries started to recover slowly in early 2010 , the unemployment rate continued to increase, rising 0.4 percentage points to 8.8 per cent (International Labour Organization, 2011). In the United States, the unemployment rate increased by 4.7 percentage points from 2007 through 2009, and continued to increase by 0.3 percentage points to reach 9.6 per cent in 2010 (United States Department of Labor, Bureau of Labor Statistics, 2011).

Although the rate had dropped to 8.9 per cent by the end of February 2011, projections indicate that it will take several years before the unemployment rate in the United States returns to its pre-crisis level (United Nations, 2011). Similarly, despite improvements in employment in Germany, the average unemployment rate in the Euro area continued to drift upwards, reaching 10 per cent in 2010, up from 7.5 per cent before the crisis (United States Department of Labor Bureau of Labor Statistics, 2011).

The unemployment rate in the countries of Central and South-Eastern Europe (non-European Union) and the Commonwealth of Independent States increased by 1.8 percentage points to 10.4 per cent-with unemployment rising by more than 3 million to reach 18.5 million-to register the highest regional rate in the world at the end of 2009 (International Labour Organization, 2011).Latvia recorded one of the steepest increases in the rate of unemployment in the region, rising from 6 per cent in 2007 to 17.1 per cent in 2009. In Estonia and Lithuania, unemployment rates went from being among the lowest on the continent to being among the highest, rising by more than 9 per cent in each case to reach unemployment rates of 13.8 and 13.7 per cent, respectively.

In these three countries, the unemployment rate had declined for an average of seven years prior to the crisis (Eurostat, 2011).

The effects of the crisis on unemployment in other regions have been quite different and raise other employment and income concerns. In East Asia, for example, the initial impact of the crisis was quite severe: 20 million workers in China, comprising more than 15 per cent of the estimated 130 million internal migrant workers, were retrenched. In Malaysia, 12,600 workers were retrenched in the first quarter of 2009. Although the number is small in absolute terms, it is nearly four times the 2008 average quarterly number of retrenched workers of 3,460. More than three fourths of the retrenched workers in the first quarter of 2009 were in manufacturing. The Ministry of Manpower and Transmigration of Indonesia reported more than 51,000 job losses, while the Indonesian Employers Association reported more than 237,000 layoffs between October 2008 and March 2009. Between September 2008 and February 2009, employment in the garment sector of Cambodia contracted by 15 per cent. In the Philippines, the number of persons unemployed increased by 6.7 per cent between January 2008 and January 2009. Between March 2008 and March 2009, the number of unemployed persons in Thailand increased by a staggering 73.3 per cent; the number of people on unemployment in surance rose by 17.2 per cent in January 2009 alone, after having risen in 2008 by 38.3 per cent over the previous year (Huynh and others, 2010). In total, unemployment in the region increased by almost 16 per cent to reach 37.6 million people at the end of 2009. Similarly, the unemployment rate increased to 4.4 per cent of the workforce in 2009 from 3.8 per cent in 2007. An improvement in domestic employment in China, as well as the positive spill over effects that its economic growth has had on neighbouring countries, has led to an improvement in economic and employment figures for the region. The regional unemployment rate is estimated to have declined to 4.1 per cent in 2010 (International Labour Organization, 2011).

In Latin America and the Caribbean, where the economies are closely tied to the United States and European markets, the unemployment rate increased from 7.0 per cent in 2008 to 7.7 per cent in 2009 . The rate is estimated to have remained fairly stable in 2010, but remains above the global average and that of the three Asian sub-regions (Economic Commission for Latin America and the Caribbean and International Labour Organization, 2010).

In most other developing regions, unemployment rates remained stable or showed marginal declines, and there was little change in the numbers unemployed. However, the changes in the unemployment rate do not 
reflect the full impact of the crisis on employment in these regions, which also involves increased informal economy employment, vulnerable employment and working poverty.

There have been large increases in both informal and vulnerable employment in developing regions. Where the effect of the crisis was most telling in the region was its effect on the unemployment rate for women. While the rate of unemployment among males dropped by 0.6 percentage points between 2007 and 2009, the unemployment rate for females increased by 0.4 percentage points (International Labour Organization, 2011).

In developed countries, there is evidence of rising long-term unemployment and lower participation rates even in countries with employment growth. Experience shows that these trends are difficult to reverse. The risk is that this situation will threaten the level of output and thus longer-term prosperity. The number of people in long term unemployment - persons unemployed for more than one year-has increased in all countries for which data are available. In addition, in more than 80 per cent of these countries, the share of the long-term unemployed in total unemployment has increased, underscoring that long-term unemployment is growing faster than overall unemployment (International Labour Organization International Institute for Labour Studies, 2010).

Many countries are also witnessing increased numbers of discouraged workers, that is, working-age individuals willing to work but no longer actively seeking employment. Nearly two million people have become discouraged from actively looking for jobs. There is also the danger that more people will leave the labour market entirely; nearly four million workers left the labour market at the end of 2009 (International Labour Organization International Institute for Labour Studies, 2010). Worker discouragement is much higher among younger and older workers.

In the face of weak job creation, underemployment-in the form of shorter working hours or involuntary part-time employment-has also increased rapidly in many countries. For example, since late 2009 part-time job growth has accounted for 40 per cent of the growth in employment in Australia, Canada and the United States. For the affected workers this has meant reduced incomes owing to shortened work periods and deteriorating working conditions. In developing countries, where most workers simply cannot afford to be unemployed, underemployment usually takes the form of informal employment. The informal economy often provides the only means of survival for low-skilled workers who need to support their families when formal sector job opportunities are unavailable. As workers laid off from the formal economy turn to the informal economy, their work becomes characterized by lower earnings, lower productivity, more difficult working conditions and the increased risk of poverty.

\section{Informal and vulnerable employment}

As the global economy expanded over recent decades, job growth lagged behind economic growth to produce "jobless growth", accompanied by the increased casualization of employment and growth in part-time jobs at the cost of fulltime jobs. As more formal sector jobs have disappeared, the informal economy and other precarious jobs have served as a major buffer for laid off workers. In developed and middle-income countries, non-standard work arrangements, such as temporary work and contracting or outsourcing, have increased significantly (Kalleberg, 2009; Organization for Economic Cooperation and Development, 2009). In developing countries, the informal economy employs up to 60 per cent of the workforce and produces close to 40 per cent of GDP (Bacchetta, Ernst and Bustamante, 2009; Ihrig and Moe, 2004). The share of informal employment in most developing countries has increased significantly in the last few years as a result of the Great Recession of 2008-2009.

From Asia's massive garment industry to sub-Saharan Africa's low-level leather industry, selfemployed (own-account) workers, as well as unpaid family workers, have become increasingly connected to the global economy. This coupling of the formal and informal economies has meant that the informal economy is being increasingly affected by economic recessions in much the same way as the formal economy.

Consequently, the Great Recession has subjected informal firms and workers throughout the developing world to lower earnings because of decreased demand, lower prices, fluctuations in interest and exchange rates and reduced access to financial services. Furthermore, the huge inflow of laid-off workers, returning migrants and new labour market entrants into the informal economy has also increased competition for jobs among such workers, placing further downward pressure on wages in the informal economy (Cling,Razafindrakoto and Roubaud, 2010).

In Asia, both self-employed and subcontracted home-based workers reported increased numbers (Horn, 2010). A study published by the Asian Development Bank Institute noted that a larger adjustment to retrenchments in developing Asia has been the shift to informal and vulnerable employment (Huynh and others, 2010). For example, in Indonesia, the number of casual workers not in agriculture increased by 7.3 per cent from February 2008 to February 2009. In Thailand, in the first quarter of 2009, the total number of own-account and contributing family workers increased by an astounding 566,000 over the previous year. In the first quarter of 2009 , the number of wage employees grew by only 0.6 per cent, whereas those in vulnerable employment 
increased by 3.2 per cent (Economic Commission for Latin America and the Caribbean and International Labour Organization, 2010). There are so many people in Thailand supplementing their incomes by gathering plastic water bottles for recycling that the price offered for such bottles has dropped (Turk and Mason, 2010). In Cambodia, "cycle" (tricycle rickshaw) riders reported that the number of cycles on the streets had increased; such work is more attractive to the self-employed as the start-up costs are low. In India, the Self Employed Women's Association (SEWA) recently estimated that, due to the economic crisis, the decline of key industries, such as diamond cutting and polishing in the city of Ahmadabad in Gujarat State, had caused an increase of almost 25 per cent in the number of informal workers and recently retrenched formal workers seeking work in construction (Horn, 2010).

In 2009, half of the world's workers-nearly 1.53 billion people-were in vulnerable employment. While the global share of workers in vulnerable employment has been declining, the crisis has slowed the decline in some regions and even reversed the downward trend in others. Yet, the number of workers in vulnerable employment has increased in most regions, except for the developed economies and the European Union, Central and South-Eastern Europe (non-European Union), and the Commonwealth of Independent States and

East Asia, where there had been some decline (International Labour Organization, 2011). Vulnerable employment was a significant problem before the crisis in South-East Asia and the Pacific, South Asia and subSaharan Africa, and this situation remains unchanged. More than three quarters of all workers in South Asia (78.5 per cent of total employment in 2009) and sub-Saharan Africa (75.8 per cent) are in vulnerable employment, and about two thirds of workers in South- East Asia and the Pacific (61.8 per cent) are in a similar predicament. The severity of the problem in South Asia and sub-Saharan Africa was clearly exacerbated by the crisis: over the period 2007-2009, vulnerable employment increased in South Asia and sub-Saharan Africa by 15.1 and 11.7 million respectively, with more than half the increase taking place in 2009 alone (International Labour Organization, 2011).

The burden of vulnerable employment continues to fall heavily on women and youth, who work mainly in the agricultural and informal economy. In 2009, the share of women in vulnerable employment was 84.0 per cent compared to 69.5 per cent for men (International Labour Organization, 2011). The majority of Asian workers did not enjoy the security provided by formal salaried employment even in the pre-crisis period. As a result of the crisis, the number in vulnerable employment in South-East Asia and the Pacific increased by 5.4 million to 173.7 million between 2007 and 2009. Even before the onset of the global economic crisis, an estimated 164 million workers were in vulnerable employment, that is, more than ten times as many as the number of people unemployed in the sub-region (International Labour Organization, 2011).

In Latin America and the Caribbean, the positive impact on labour markets of several consecutive years of fairly high economic growth can be seen in the reduced share of vulnerable employment. Between 2003 and 2008 , the vulnerable employment rate decreased by 3.8 percentage points. Nevertheless, based on currently available information, the rate of vulnerable employment in Latin America and the Caribbean increased in 2009 by 0.4 percentage points (International Labour Organization, 2011). The increase in vulnerable and informal jobs is worrying as they offer little or no entitlement to redundancy pay or other compensation that workers could use to retrain or serve as a buffer against the income shock associated with job loss. The link between growing informalization and the lack of social protection poses major challenges to workers, employers and Governments as it affects poverty levels and income distribution (Barrientos and Barrientos, 2002; Organization for Economic Cooperation and Development, 2009).

\section{Working poor}

The working poor are those who are employed but live in households where individual members subsist below the established measure of income poverty. The reason these people are poor is not because they do not work; they are poor because despite working they cannot earn enough to get out of poverty. In many developing countries, most adults who are poor also work. Their predicament is compounded by the fact that, in many of the countries where they live, there is no unemployment insurance or other form of universal or targeted social protection. In the most vulnerable group of countries, more than 80 per cent of the population has no social security coverage and no access to health services (International Labour Organization, 2010b). The harsh reality facing the working poor is that, in order to survive, a person must either work for an income- no matter how menial that work is - or be dependent upon someone who does work.

Working poverty shares many of the characteristics of extreme poverty. The majority ( 75 per cent) of the world's working poor live in rural areas, a feature not far removed from the high incidence of poverty among agricultural wage workers, largely due to seasonal unemployment and the low wages available on small farms. Similarly, just as women comprise a higher share of the world's poor, they constitute an estimated 60 per cent of the working poor (International Labour Organization, 2004a). 
At the global level, working poverty has been decreasing in both absolute terms and as a share of employment, but the global crisis has significantly slowed progress. From 1999 to 2009, working poverty declined by 13.2 percentage points and the number of working poor fell to 631.9 million, using the $\$ 1.25$ a day threshold to estimate their numbers. However, had poverty declined at pre-crisis rates, the number of working poor would have fallen by an additional 40 million persons (International Labour Organization, 2011). When working poverty is measured by the $\$ 2$ a day poverty line, the impact of the crisis has been to reduce the number of working poor by 42 million fewer than would have been expected had the pre-crisis trends continued unchanged.

In the past decade, the share of working poverty ( $\$ 1.25$ a day) has fallen most rapidly in East Asia, South-East Asia and the Pacific, and South Asia, with reductions of 29.7, 22.6 and 13.1 percentage points, respectively. Despite the slowdown caused by the crisis, these areas continued to show positive reductions in working poverty, with rates falling by 0.7 to 1.4 per cent from the levels in the period 2008-2009. In all other regions, progress has stagnated or even reversed. Using the $\$ 2$ a day poverty line, the comparative resilience of East Asian employment is even more marked. East Asia managed to lower working poverty at this level of income by about 2.7 percentage points from that in the period 2008-2009.

The number of working poor (earning below $\$ 1.25$ a day) in sub-Saharan Africa remains high, increasing by 4.4 million people in 2009 , to 174 million, although the share of the working poor in employment remained unchanged (International Labour Organization, 2011). Latin America and the Caribbean showed slightly elevated vulnerability at the $\$ 2$ a day poverty line between 2008 and 2009.

\section{Impact of the crisis on wages and salaries}

The massive loss of jobs worldwide has been accompanied by stagnation, decline or loss of wages. In both developed and developing countries, shrinking tax revenues have resulted in significant declines in national and local government funding of public institutions. Private sector profits have plummeted, while universities and not-for-profit organizations have suffered heavy endowment losses. In response to shrinking budgets and available resources, public and private institutions and companies have attempted to prevent massive layoffs by reducing personnel costs through various means, including job furloughs (unpaid days off), shorter work weeks, wage cuts or freezes, renegotiation of workloads, temporary stoppages, and phased or early retirements.

These changes have had a huge impact on wages and salaries, and hence on the living standards of workers and their families (Belser, 2010; Couch, Jolly and Placzek, 2009). As laid-off workers have suffered from lost wages, high levels of unemployment have exerted downward pressure on the wages of those employed. In the United States and across the countries in the 27-member European Union, wages have declined as full-time workers were forced to accept reduced working hours because of severe budget deficits (O'Farell, 2010). For example, workers in Estonia saw a 7.4 per cent year-on-year decline in average wages in the first quarter of 2009 (European Foundation for the Improvement of Living and Working Conditions, 2010).

In California, state workers lost $\$ 2.01$ billion in wages and benefits during fiscal year 2009/10 as a result of the mandated three days of furlough a month each worker must take (Jacobs, 2009).

Globally, it is estimated that the growth in average monthly wages slowed from 2.8 per cent in 2007, on the eve of the crisis, to 1.5 per cent in 2008 and 1.6 per cent in 2009. If China is excluded from the aggregate, the global average wage growth drops from 2.2 per cent in 2007 to 0.8 per cent in 2008 and 0.7 per cent in 2009 .

In the advanced economies, real wages declined by 0.5 per cent in 2008 after rising by 0.8 per cent in 2007 , and rose by only 0.6 per cent in 2009 .

In Central and Eastern Europe (non-EU and Commonwealth of Independent States), real wages fell by 0.1 per cent in 2008, following growth of 4.6 per cent in 2008 and 6.6 per cent in 2007. In Latin America and the Caribbean, the growth of real wages decelerated to 1.9 per cent in 2008 and by 2.2 per cent in 2009 , from 3.3 per cent in 2007 (International Labour Organization, 2011).

Large declines in real wages do not augur well for national and global economic recovery efforts. Prolonged periods of economic stagnation are often preceded by wage deflation because workers have less money to spend on key drivers of growth, such as consumption of durable goods and services. In addition to lowering domestic demand, lower wages also affect the ability of workers who had sustained high levels of consumption through the utilization of credit to repay their debts. High levels of credit default can affect the health of the financial system as well. For workers whose family incomes place them at or near the poverty line, any deceleration in wages has the potential to push them into poverty. In addition, lost wages affect employee morale and increase stress, both of which are factors often linked to lower productivity among workers.

At the same time, the number of displaced workers has increased globally. Past recessions have shown that, while some of these workers may have begun to find jobs in a recovering global economy, their postrecession wages, particularly for older workers, are likely to be much lower (Rodriguez and Zavodny, 2000).

For example, United States workers displaced during the period 1981-1995 who found other jobs were 
paid real weekly earnings 13 per cent less than their predisplacement earnings (Farber, 1997). This drop in earnings is due to a number of reasons.

First, laid-off workers tend to lose seniority-related benefits accrued with previous employers.

Second, they are often confronted with a post-recession labour market requiring different skills sets.

Third, new employers often do not adequately compensate fresh workers for skills that they had acquired on a lost job. Hence, while the global economy has begun to recover, it is not certain that today's displaced workers will be able to find jobs that will compensate them at pre-recession levels. Any significant wage shortfalls will diminish their purchasing power, adversely affecting their everyday livelihoods.

To improve their future earnings potential, these workers will have to retool their work skills. Many Governments have been proactive in this area, adopting a wide range of training policies to ensure the employability of such workers.

\section{Adverse impacts on demographic and social groups}

While the global unemployment rate rose by only 0.6 percentage points from 2007 to 2010, this average figure obscures the quite varied realities in different regions about the extent to which the employment of men, women and young people has been affected by the crisis . Some of these outcomes can have significant long-term consequences for individuals and households that may persist even after the economic recovery has occurred. Globally, the number of unemployed men stood at 118.4 million in 2010, an increase of 17 million since 2007, while the number of unemployed women stood at 86.5 million in 2010, up 10.6 million since 2007 (International Labour Organization, 2011). However, women have been adversely affected not only by high levels of unemployment, but also by underemployment, low wages and reduced participation in the formal economy. Evidence from developing regions suggests that women have been negatively affected by labour force segregation.

Most layoffs in the Philippines have been in the export processing zones, where 75 per cent of the workers are women. In Thailand, the number of women in manufacturing decreased to 130,000 in late 2008, and women accounted for 63.2 per cent of the total decrease in employment in this sector (New farmer these are workers who joined the ranks of the unemployed because their positions were eliminated, their company closed, or their jobs were lost to countries with lower labour costs 2009). Similarly, a third of the 30,000 mostly women workers in "maquila" factories in Nicaragua, who produce garments and other export goods, lost their jobs (Green, King and Miller-Dawkins, 2010). In the Middle East and North Africa, strong cultural, social and economic gender divisions in the work force continue to favour males over females. Some employers openly prefer male job-seekers, while others prefer women for only low-skilled and low-paid work (International Labour Organization, 2010c). In these regions, employment is male-dominated, and there are even fewer opportunities for women in tight labour markets (Dhillon and others, 2009).

However, for the most part, men in developed economies have fared worse than women, as they are concentrated in those sectors most seriously affected by the crisis, particularly construction and the manufacture of durable goods. In the United States and Europe, more than 6 million jobs were lost in manufacturing,2.8 million in construction and 2.3 million in wholesale and retail trade-sectors largely dominated by male workers. Employment in these sectors continues to decline further and faster than those with more women, such as the public sector, health care and education (International Labour Organization, 2010d).

Women also tend to be over represented in vulnerable and informal employment in most countries. They have access to fewer good-quality jobs within the formal economy than men. Their incomes are lower, they are less protected by social security and usually get more precarious work, such as domestic service and other care work. Many employers in the informal economy who hire large numbers of women have been affected by decreased demand, while many have taken advantage of the new situation to reduce employee rights and remuneration. Many women in the informal economy thus face job loss, poorer work conditions and more casual employment contracts.

The global recession has also affected women's wages at least as much as those

of men. Wage data for 22 countries indicate that the gender gap in pay did not change in 2008. Women still earned wages about 80 per cent of those earned by men (International Labour Organization, 2009a). However, in some countries, the gender pay gap has worsened. In the United Kingdom and the United States, the gender pay gap increased in 2008, reversing gains in earlier years. Youth as a group have also been strongly affected by unemployment, having entered the crisis with unemployment rates well above those of their older counterparts. The global youth unemployment rate stood at 12.6 per cent in 2010, up from 11.8 per cent in 2007 (International Labour Organization, 2011). Even before the global economic downturn, youth already faced an employment crisis and higher risk of low pay. In all regions of the world, youth (aged 15-24 years) have been (A factory in Latin America that imports materials/equipment duty/tariff-free for assembly/ manufacture and then re-exports the finished products to the country of origin or elsewhere.) more likely than adults to be unemployed. This situation has existed at least since the mid-1990s, with the ratio of the youth-to-adult 
unemployment rate reportedly as high as 3.5 in 2003 (International Labour Organization, 2004b; 2008). Although this ratio has declined since then, early estimates still place the ratio between youth and adult unemployment rates at 2.7 in 2009 (International Labour Organization, 2010e). Moreover, in most regions over the period 2007-2009, youth unemployment rose more sharply than for adults. and in 2009, more than 79 million young people aged 15 to 24 years were unemployed, one of the highest levels ever.

The global youth unemployment rate is expected to remain at about 13 per cent through 2010 (International Labour Organization, 2011). Regardless of the observed regional and country-level differences, the evidence indicates that, on average, crisis-induced job losses have affected youth more seriously and more immediately than adults, suggesting that young people are more disadvantaged with regard to job placement, wages and job security. International Labour Organization (2010e) observed "significant consequences for young people as upcoming cohorts of new entrants join the ranks of the already unemployed" and warned of the "risk of a crisis legacy of a 'lost generation' comprised of young people who have dropped out of the labour market, having lost all hope of being able to work for a decent living". Also the job market for youth is likely to recover more slowly than that for adults, the number of young people stuck in working poverty will continue to grow while working poverty will likely persist for at least another generation. Among young people, young women find it more difficult to find work, with early estimates putting the female youth unemployment rate in 2009 at 13.2 per cent compared with the male rate of 12.9 per cent (International Labour Organization, 2010e).

Youth unemployment, exacerbated by the crisis, can have long-term effects on the social trajectory of youth, their families and their communities (International Monetary Fund and International Labour Organization, 2010). University and college graduates can be negatively affected in terms of their placement with firms, their potential earnings and prospects for job mobility. In most cases, the negative effects last slightly more than a decade before these workers eventually move to higher-paying firms. Studies in Canada and the United States have demonstrated the poorer employment prospects of graduates during periods of economic downturn: recent graduates normally start in less attractive firms or simply take up low-paying jobs (Kahn, 2009; Oyer, 2006).

For example, students who graduated during the United States recession of the 1980s earned 7-8 per cent less in their first year than those who had graduated in better times (Kahn, 2009) More recent evidence points to a similar labour market phenomenon as a result of the recent crisis (Rampell, 2011). In Canada , labour market entrants during past recessions suffered initial earning losses of about 9 per cent, which were only offset after about 10 years (Oreopoulos, Von Wachter and Heisz, 2006). Furthermore, poor early experiences in the labour market undermine the future marketability and earning potential of those who graduate during hard times.

In addition, long-term unemployment and underemployment can have debilitating psychological effects on young workers, which may lead young people to withdraw from the labour market altogether (International Labour Organization, 2010e). In some cases, the decline in youth labour market participation is compensated by increased education enrolment as the opportunity cost of staying in school longer can be lower when labour market opportunities are depressed. Where this has not occurred, the probability of discouragement increases, making youth more apathetic in both seeking employment and furthering their education. Based on this historical experience, as well as on more recent anecdotal evidence, youth who become unemployed or enter the labour market during a time of crisis are likely to face longer spells of unemployment in the future, or become stuck in low-wage employment (Arulampalam, Gregg and Gregory, 2001; Böheim and Taylor, 2002; Gregg and Tominey, 2005; Murray, 2009).

As with women and youth, older workers, indigenous peoples, migrant workers and ethnic and religious minorities also face bias in the labour market. Among different groups of workers, overseas migrant workers, particularly newly arrived migrants, are perhaps most seriously disadvantaged and often among the first to lose jobs. In many cases, they have invested heavily in getting recruited and travelling to work in a foreign country. Therefore, returning to their home country is often not an option, and they are more likely to accept almost any terms just to retain their jobs. And when they have lost their jobs and work permits, they become illegal or undocumented, forced to turn to income opportunities in the informal or shadow economy. For indigenous groups, unemployment has tended to be higher than the average for the general population, and this situation has worsened since the crisis. In Australia, for example, the gap in unemployment rates between indigenous and non-indigenous populations increased from 9.6 to 12.6 per cent between 2007 and 2009 (Drape, 2010).

Older workers who lose their jobs tend to encounter greater difficulty in finding new work than younger workers. In the United Kingdom, out of work men in their 50s only had a one-in-five chance of being in a job two years later; the longer they remained unemployed, the worse were their chances of finding employment. In addition, many cannot afford to wait for the value of their pension savings to recover before drawing upon their retirement benefits (Age Concern and Help the Aged, 2009). At the same time, older persons, especially in developed economies, have seen their incomes shrink as the value of their pension funds 
has fallen. In the OECD countries, private pension funds lost 23 per cent of their investment value in 2008, equivalent to $\$ 5.4$ trillion in aggregate (Organization for Economic Cooperation and Development, 2009). The impact of the decline in private pensions has been greatest in countries such as Australia, Denmark, the Netherlands, the United Kingdom and the United States, where private pensions play a major role in providing old-age incomes. In addition, underfunded pension schemes have become financially vulnerable. For example, in the United States in 2010, for the first time since the Social Security Amendments of 1983, annual Social Security outlays exceeded revenues by some $\$ 29$ billion (Congress of the United States, Congressional Budget Office, 2010).

For older persons in developing countries, most of whom are not covered by social security or other retirement income schemes, the financial crisis increased their vulnerability. Although there has been little evidence concerning the impact of the crisis on older persons in developing countries, selected survey data are becoming available. For example, the non-governmental organization Age-Well's survey of over 1,500 persons aged 55 years and older throughout India found that many older persons have taken measures to mitigate the effects of the recession by returning to work and by reducing expenses on recreational facilities and luxuries.

Older public sector workers have postponed plans for voluntary retirement. The majority (60 per cent) of the survey respondents owned stocks, with 80 per cent of them having lost money in their stock trading accounts (Alvi, 2009).There have also been visible effects on household incomes. In the United States, the net worth of the average American family was reduced by about 20 per cent, the largest such decline since the end of the Second World War (Warner, 2010). In the United Kingdom, during the period 2007-2009, real incomes decreased for many households, especially those with heads of households between 25 and 34 years of age. Households with children experienced greater decreases in income than childless households, while households with more children suffered greater decreases in income than those with fewer children (Howell, Leaker and Barrett, 2010). In developing regions, increased working poverty has reduced household income levels.

\section{Impacts on household dynamics and human development}

The impact of the crisis on income and employment prospects has also affected the dynamics in households and families. When household incomes decline, gender differences grow in terms of time use, particularly with respect to unpaid work, as women take on even larger shares of unpaid work and care giving responsibilities. For the most part, the difference in time use by males and females has remained unchanged.

However, in developed economies, where men have been most severely affected by the crisis, incomegenerating and care-giving roles have been reversed in more households and the number of stay-at-home fathers has increased. In the United States, the number of households with mothers as the only working spouse rose by 1.5 per cent between 2008 and 2009. At the same time, the number of households with two working spouses decreased by 2.9 per cent, suggesting that more females becoming sole breadwinners may be linked to their male partners being laid off or retired early (United States Department of Labor, Bureau of Labor Statistics 2010).

The effect of the crisis on migrant workers has dealt a huge blow to household income and family dynamics in developing countries. Migrant remittances are key to the welfare of recipient families and communities, but officially recorded remittances fell by 6 percentage points between 2008 and 2009 (United Nations Children's Fund, 2010). This probably implies that many more households have become poorer than would have been the case otherwise. Many families have been forced to rely on social assistance where available, adding to the strain on economies already hampered by slow economic growth (see Cortina, 2009, for the case of Mexico). To cope with the crisis, many women in Vietnam, for example, have moved to the informal economy, or increasingly rely on community-based assistance programmes (Nguanbanchong, 2010).

The effect of the crisis on children has also been significant. In both developed and developing countries, reduced family incomes have required parents to adjust consumption patterns, including by making cuts in health and education expenditures. A weak or moribund economy affects the educational attainment of students from middle- and low-income backgrounds. Parental job loss increases by about 15 per cent the probability that a child will have to repeat a grade in school (Stevens and Schaller, 2009). In addition, such students may not be able to afford the required tuition and other out of pocket expenses.

On the other hand, the opportunity cost of staying in school longer can be lower when labour market opportunities are depressed. As demonstrated in past crises, a consequence of the current crisis is likely to be increased child labour. For example, in the Philippines during the 1997-1998 Asian financial crisis there was a drop in school enrolment rates while child labour rose among 10-14-yearolds.There was also an observed increase in the labour exploitation of girls in Indonesia and Thailand. When parents cannot afford school costs or the loss of a child's potential contribution to household income, children are more likely to stop attending school and to begin work at an early age. Where the current crisis and fiscal austerity measures lead to education budget cuts, or if international support for education is reduced, the number of children who leave, or never attend, school to join the ranks of the child labour force could also increase. Among the most important 
factors that have contributed to recent declines in child labour were increased efforts to extend education, with the abolition of school fees at the primary level and extension of coverage to junior secondary education. There is already a serious concern that the impact of food price increases in many developing countries has had a negative impact on school attendance, leading to increasing numbers of children joining the workforce. Some countries were especially vulnerable to the economic crisis due to measures already taken in response to the food crisis, which overstretched their fiscal capacity. There is also the added gender dimension: when poor families have to make a choice between sending a boy or girl to school, studies have shown that, even under pre-crisis conditions, parents often choose to invest in the education of their sons, for example, so as to not lose their daughters' more significant contributions to housework.

\section{Conclusion}

The crisis is slowing progress in human and social development due to the combination of falling incomes owing to job losses and increased vulnerable employment, higher proportions of household expenditure spent on basic needs, worsening nutritional outcomes and more limited coping mechanisms. The longer crisis induced distress in labour markets persist, the more workers, their families and their communities will be at risk of being trapped in long-lasting poverty. The ongoing cuts in public social spending in some countries can only serve to further increase the number of working poor and to heighten inequities and inequalities. Rising fiscal pressure in poor countries, particularly those heavily dependent on exports, may also lead to cutbacks in public expenditure on basic services (Sanchez and Vos,2009).

Therefore, much needs to be done to quell, if not reverse, the ongoing jobs crisis. The stimulus measures implemented by Governments since the onset of the crisis have succeeded not only in supporting economies but also in avoiding further significant job losses. However, the ongoing wave of fiscal austerity measures may slow the creation of jobs and delay employment recovery. In addition, developing countries with limited fiscal space have experienced difficulties in overcoming the effects of the crisis and face significant challenges in their efforts to achieve a more sustainable recovery. With the informal economy serving as a buffer for laid-off workers and helping to absorb new labour market entrants who cannot find jobs in the formal sector, high levels of informal and vulnerable employment are likely to continue well beyond the crisis. The policy debate at the national and international levels has been heavily tilted towards addressing the employment crisis in the formal economy, while very little attention has been paid to the informal economy. It is important that the challenges facing the informal economy be addressed both from the perspective of enhancing longterm, competitive productive capacity and of improving the job and income security of informal workers.

Economic recovery will not be achieved until the employment situation improves in a sustainable manner. However, to restore employment, even to pre-crisis levels, economic growth should be sufficiently robust to also compensate for increases in the size of the working population. Yet, restoring Employment to pre-crisis levels is insufficient because the period preceding the crisis was remarkable for its "job-poor" or "jobless growth". It is thus important to set employment goals beyond the pre-crisis levels. This will require that priority be given to job and income security with greater emphasis on the creation and sustainability of decent work and social protection. The experience of the 1997-1998 Asian financial crisis shows that many countries did not regain their pre-crisis employment levels until employment and social protection goals were put at the centre of economic and social policies. Without social protection, working poverty is likely to increase in most developing countries. A prolonged jobs crisis harbours major risks for social and political stability, and the increasing burden of unemployment on young people seriously challenges the ability of Governments to maintain social cohesion. It is essential to take measures to ensure that youth, women, older persons, persons with disabilities, indigenous peoples and other groups are not discriminated against in the labour market. It is therefore critical that well-designed active labour market policies be put in place to support job search assistance, retrain the unemployed, improve public employment services and facilitate school-to-work transition for these vulnerable groups. These measures imply more public spending, counter to the austerity measures being adopted in some major industrialized economies. However, the timing and sequence of the austerity measures will be critical to achieving a smooth recovery. In the near term, such measures to reduce unemployment can boost budget balances and lead to fiscal deficits not necessarily higher than those under austerity policy responses alone. Therefore, an effective economic recovery requires an exercise in effective policy coherence-involving macroeconomic policies, employment generation and social policies.

\section{References}

[1]. Baker, Dean and David Rosnick. 2003. "Too Sunny In Latin America? The IMF’s Overly Optimistic Growth Projections and Their Consequences.”CenterforEconomicandPolicyResearch Briefing Paper,..cepr.net/documents/publications/econ_growth_2003_09.pdf Baker, Dean and Rivka Deutch. 2009. "The State and Local Drag on the Stimulus." Center for Economic and Policy Research,.://www.cepr.net/documents/publications/stimulus-200905.pdf.

[3]. Baker, Dean. 2009. "Housing Market Monitor: Mortgage Applications Surge as Homebuyers Seek to Benefit from Tax Credit." Center for Economic and Policy Research, October. 
[4]. Bond, P. and Manyanya, M. (2002) Zimbabwe's Plunge: exhausted nationalism, neoliberalism and the search for social justice. Durban: University of KwaZulu-Natal Press.

[5]. Carmen M. Reinhart, Carmen M. and Kenneth S. Rogoff. 2009. "The Aftermath of Financial Crises.”American Economic Review 99 (May) 466-www.economics.harvard.edu/faculty/rogoff/files/Aftermath.pdf

[6]. Center for Economic and Policy Research (CEPR). 2009. "Event: IMF-Supported Macroeconomic Policies and the World Recessio A Look at Forty-One Borrowing Countries." Panel discussion,October 15. http://www.cepr.net/index.php/events/events/imfsupported-macroeconomic-policies-andthe-world-recession/.

[7]. Cordero,Jose A."TheIMF'sStand-byArrangementsandthe EconomicDownturnin Eastern Europe:TheCases of Hungary,Latvia,and Ukraine.”Centerfor Economicand PolicyResearchBriefing Paper,September.http://www.cepr.net/documents/publications/imf-200909.pdf

[8]. Crippler,G.R.2012)Capitalizingoncrises.Cambridge:HarvardUniversityPress.Dohlman,PeterandBikasJoshi.2009."ReformedIMFLen dingHasWorkedWellInCrisis.”IMFSurvey Magazine..://www.imf.org/external/pubs/ft/survey/so/2009/POL092509A.htm

[9]. Haring, N. and Douglas, N. (2012) Economists and the powerful: Convenient theories, distorted facts, ample rewards. London: Anthem Press.

[10]. Harman, C (1966), 'The Crisis of Bourgeois Economics', International Socialism, 71; available at http://pubs.socialistreviewindex.org.uk/isj71/harman.htm://paecon.net/PAEReview/issue52/Kellecioglu52.pdf [Accessed 6 December 2012]

[11]. http://www.cepr.net/index.php/data-bytes/housing-market-monitor/mortagage-applications-surge/

[12]. IEO (Independent Evaluation Office of the IMF). 2003b. "Fiscal Adjustment in IMF-Supported Programs." September.http://www.ieo-imf.org/eval/complete/pdf/09092003/all.pdf

[13]. IEO (Independent Evaluation Office of the IMF).2003a. "EvaluationReport IMF and Recent Capital Account Crises: Indonesia, Korea, Brazil.” September. http://www.imf.org/external/np/ieo/2003/cac/

[14]. IMF Survey Magazine. 2009. "Quick, Forceful, Cooperative Action Needed on Crisis-IMF." October 9. http://www.imf.org/external/pubs/ft/survey/so/2008/new100908a.htm

[15]. IMF. 2009c. "Review of Recent Crisis Programs." September. http://www.imf.org/external/np/pp/eng/2009/091409.pdf.

[16]. IMF. 2009c. "World Economic Outlook: Sustaining the Recovery." http://www.imf.org/external/pubs/ft/weo/2009/02/index.htm

[17]. IMF.2009a. "Creating Policy Space-Responsive Design and Streamlined Conditionality in Recent Low-Income Country Programs." September. http://www.imf.org/external/np/pp/eng/2009/091009a.pdf

[18]. Kellecioglu, D. (2010) Why some countries are poor and some rich - a non-Eurocentric view. Real-World Economics Review, 52, pp. 40-53. Available from:

[19]. Landes, D. S. (1999) The wealth and poverty of nations: why some are so rich and some so poor. New York: W. W. Norton \& Company, Inc.

[20]. Leibbrandt, M. et al. (2010) Trends in South African income distribution and poverty since the fall of apartheid, Paris: OECD and Cape Town: SALDRU.

[21]. Maddison, A. (2001) The World Economy - a millennial perspective. Paris: OECD.

[22]. Moseley, F (2012), "A Critique of the Marginal Productivity Theory of the Price of Capital", real-world economics review, 59, pp.131-137.

[23]. Sraffa, P (1960), Production of Commodities by Means of Commodities. Cambridge: Cambridge University Press.

[24]. Zinn, H. (2005) A people's history of the United States: 1492 - present. New York: HarperCollins Publishers.Grieve, R H (2012), 'The marginal productivity theory of the price of capital. An historical perspective on the origins of the codswallop', real-world economics review, 60, pp. 138-149. http://www.paecon.net/PAEReview/issue60/Grieve60.pdf

[25]. Rosnick, David and Mark Weisbrot. 2007. "PoliticalForecasting? TheIMF's Flawed Growth Projections for Argentina and Venezuela."Center for Economic and Policy Research Briefing Paper,

April.://www.cepr.net/documents/publications/imf_forecasting_2007_04.pdf

[26]. Weisbrot, Mark and Luis Sandoval. 2007. "Argentina's Economic Recovery: Policy Choicesand Implications." Center for Economic and Policy Research,October. http://www.cepr.net/index.php/publications/reports/argentinas-economic-recoverypolicy-choices-and- mplications/

[27]. Weisbrot, Mark, Rebecca Ray, Jake Johnston, Jose Antonio Cordero and Juan Antonio Montecino. 2009. "IMF-Supported Macroeconomic Policies and the World Recession: A Look at Forty-One Borrowing Countries." Center for Economic and Policy Research Briefing Paper, October. http://www.cepr.net/documents/publications/imf-2009-10.pdf

[28]. Aghion P. et. al. 1999. 'Inequality and Economic Growth: The Perspective of the New Growth Theories.' Journal of Economic Literature. Vol. XXXVII. December. 